\title{
Reception and Application of Information Literacy Instruction in Portuguese Academic Libraries ${ }^{1}$
}

\author{
Tatiana Sanches \\ Instituto de Educação, Universidade de Lisboa, Alameda da Universidade, \\ Lisbon, Portugal, \\ tsanches@fpie.ulisboa.pt
}

\begin{abstract}
Over the past decade, information literacy has been a challenge for academic libraries in Portugal. Lately, academic library professionals all over the country have been providing a consistent foundation for both teaching sessions and guidance for students. In this article a systematic literature review is used, in an attempt "to identify, appraise and synthesize all the empirical evidence that meets pre-specified eligibility criteria to answer a given research question" [1].The aim is therefore to carry out a review that seeks to systematize the state of knowledge about information literacy instruction, trying to answer the research question: how is literacy instruction conducted and provided in Portugal? The objective was to achieve an overview of the practices of information literacy instructional training in a south European country. The overall contribution to the field of IL is mainly a focus on the state of the art of information literacy instruction in Portugal.
\end{abstract}

Keywords: Academic libraries, Information literacy training, Portuguese university libraries.

\section{Introduction}

Information literacy (IL) is a field of studies that includes a large number of theories, themes and conceptual references. The intention of a thorough study on a national scale is to seek to understand how the global reality is shaped in this specific case. The idea of this research is to understand the expression of IL training, which acts as a bridge between theoretical knowledge and practices, in the field of user education, nearing the understanding of the international discourse and its guidelines to national realities.

Portugal, as a European country, felt the influences and framed the senses of modernity, albeit in a context relatively delayed in time. Nevertheless, in the school

${ }^{1}$ The final publication is available at link.springer.com, at: http://link.springer.com/chapter/10.1007/978-3-319-14136-7 51 
setting, significant transformations emerged in the 1960s, in terms of curriculum content and organization of knowledge for training and education. Thus in the beginning of the second half of the twentieth century profound changes in the school system occurred, steepening the influences of the economy, new technological trends and social and political organization, as mechanization and mass production became an irreversible force. In the third quarter of the century sharp endogenous changes in the education system occurred, which would completely transform the educational reality in Portugal. The last decades of the twentieth century were marked by a school crisis and the tension between globalization and the model of school culture; the national resistance; and the emergence of local identities, from a popular revolution. This conflict was consistent with the growth of cultural diversity and the promotion of new forms of citizenship. Decisive transformations took place, which were intrinsic to education and schooling, such as the introduction and implementation of lifelong education and the massification of higher education. The Portuguese university libraries followed this trend and quickly adapted to the new reality, transforming their services and resources to respond to more students with more and different demands.

\section{Object of Analysis}

It is important to understand the university libraries within their host institution and insofar as they are a crucial support to the specialties it comprises. With the increasing number of students and resources at their disposal, university libraries have sought to develop and implement training programs for users. The present research was inspired by a broader investigation by the author [2] about the contribution of information literacy to university pedagogy, which sought to deepen some of these topics. The focus of this investigation arises from reflection around the training needs of users of university libraries, mainly university students. These people seek information resources in their academic libraries that enable them to meet the goals and targets proposed in the academic context. So, the question was what IL training is being provided in Portuguese academic libraries?

\section{Methodology of Analysis}

A systematic literature review was chosen, based on the credibility of the methodology. This ensures transparency of findings and is suited to a comprehensive search that ensures the inclusion of all published studies to be analyzed, thus decreasing the risk of bias. So an attempt was made "to identify, appraise and synthesize all the empirical evidence that meets pre-specified eligibility criteria to answer a given research question" [1]. There are some techniques that facilitate the 
definition of key research and strategy, as stated in The Cochrane Handbook for Systematic Reviews of Interventions [1].

To carry out a significant observation a selection of studies available on the Internet were chosen. Then, a survey was performed, both in Portuguese and English, on aggregators and portals: EBSCO HOST, B-on and RCAAP (the Scientific Open Access Repository of Portugal) that gathers the key scientific repositories of various universities and other research institutions.

The literature surveys were conducted during the first quarter of 2013. To carry out the research, date filters and document type were waived, and the search was performed instead around the key concepts that enable the achievement of meaningful expression for this investigation and combine user training and the context of the university library.

At its base were the terms user education [formação de utilizadores] and information literacy [literacia de informação] in conjunction with synonymous terms university libraries [bibliotecas universitárias] or academic libraries [bibliotecas académicas] surveyed in general word, and also the research expressions translated into English under the same scope: user education, information literacy; academic libraries or university libraries.

The EBSCO HOST portal was tested with the combination of these search terms resulting in 846 articles matching the terms. However, after application of the source filter to Portugal, only 4 items remained. These were not exactly about the research questions and therefore were excluded from the list for analysis. The same survey was carried out in the B-on portal. The combined results yielded over 45,000 references. After a limitation with the filter Portugal, only 5 articles were obtained. Of these, 1 concerned the economic value of information and 4 were related specifically to the university libraries as places of learning and training of users, namely: Amante [3]; Amante, Estremenõ Placer \& Costa [4]; Costa [5]; Segurado [6]; Segurado \& Amante [7]. Also Lopes \& Pinto [8] addressed issues of training of users in information literacy, but in another dimension. Their longitudinal study, covering about 1,000 students from various universities and sought to validate an instrument for measuring information skills, and therefore it was excluded.

All these articles were about the importance of user education in university libraries, without limiting the analysis to a particular library, to which a case study methodology or questionnaire survey had been applied to obtain results about a specific training program.

The same search was performed in the Science Open Access Repository of Portugal (RCAAP) and the combined results in Portuguese language totaled 154 references. Using the corresponding English language search terms generated almost identical outcomes with 153 references.

Naturally, redundancies were found due to the cross-search for terms and the existence of abstracts in English, in most Portuguese electronic documents. Since all the significant results found previously were replicated in this last source of information, the definitive selection was based on references found in the RCAAP. 
These results were selected primarily based on observation of the titles found and subsequently on the basis of selectivity. The selectivity criteria allowed contain the items for further analysis girded for the simultaneous matching with a set of conditions: a specific subject (user education in information literacy); the type of study and methodology (case study analysis of a reality by observation, survey, or interviews), participants (users, readers, students), and context (university library).

Combined, these conditions acted as a filter network, from which it was possible to structure a list of articles for analysis. Within the studies found, only 11 corresponded to these criteria, with a direct connection to six university libraries.

It was considered appropriate to also include the study of Teresa Costa [5], librarian at the Foundation for National Scientific Computing (FCCN), promoter of the institution on portal B-on (Knowledge Library Online) concerning the training of users of that portal, because, generally speaking, it fits the criteria presented above.

While the B-on institution is not an organic unity associated with a school or university, it is nonetheless a state entity that provides transversal services, mainly in a technological framework, promoting training for library users and assiduously being called to work in this area, particularly in university library services. That's why it is important to refer to their action and the type of training activities they promote.

I should mention that the extraction of this documentation for analysis does not exhaust the universe of programs or training schemes currently being carried out in Portugal. The purpose was to restrict the analysis to the documented and disseminated experiences and, through this circumstance, to become the exemplary community of university libraries. Thus, it can be said that an additional criterion was that these experiences were properly recorded, disclosed in the university library community, and publicized in internet national channels. The results found were sorted by the date of publication.

\section{Presentation of the Case Studies}

\subsection{Case 1 - Universidade do Minho (Minho University)}

An observation of these case studies allows us to find some similarities and specificities, and to look at the development of training programs in information literacy over the past two decades. A cross-cutting concern of professionals providing training in libraries is reported, from the beginning, with the specific needs of its stakeholders [9]. Eloy Rodrigues, of the Minho University, also addresses the need for the integration of the training curriculum level such as promoting skills and capabilities in strategy management information, for future professionals who will be in the labor market after their university education. 


\subsection{Case 2 - Universidade do Algarve (Algarve University)}

The case of the Algarve University, observable through three articles $[10,11,12]$ is considered an example of evolution and adaptation of training practices from the study of the community served over the years as well as the use of international guiding instruments for measuring the performance of the library in this area. In the article called $A$ literacia da informação e o contributo da biblioteca universitária [10] the issue of students' information skills is addressed, based on the observation of a group of undergraduate students at the Algarve University, to understand how the library can act to contribute to the improvement of their performance. This paper concludes that, despite training provided by the library, there was not at that stage a complete utilization of the resources available. A brief analysis of the data obtained showed that the skills related to the location and access of information, have fewer weaknesses than skills related to use and assessment of information. We concluded that students were not making full use of the electronic resources available, including databases for references, both in the B-on and in the library Web page. Although they demonstrate capabilities that have been developed over the course, such as locating, identifying and researching information, there was a need for students to identify the variety of types and formats of potential sources of information.

The second article [11], was a reflection about the implemented practices, stressing the need to disclose training actions, in order to reach a larger number of students, and pointed to the future path towards the realization of training programs embedded in the curriculum.

The last article [12] of the Algarve University was based on a self-assessment of the formative activity of the library. It stresses the need for systematization and continuity of training plans addressing students and the need for formal integration in the academic curriculum.

\subsection{Case 3 - Universidade Nova de Lisboa (Nova University of Lisbon)}

The case of the Nova University of Lisbon is very interesting an example of a higher education institution that was able to implement a strategy directed at the school community, of cross training to various organizational units. The article submitted by the Faculty of Science and Technology [13], is a reflection based on the results of questionnaires issued to users about the training provided within the library. The authors conclude that this training is not properly valued because its value and utility for personal and professional development is not effectively communicated. It is recommended that the training should focus on redefining its concepts, aims and objectives and their transmission to the audience more effectively. The focus is especially on communication issues involved in the training project. 


\subsection{Case 4 - B-on, Biblioteca do Conhecimento On-line (B-on)}

The article by Maria Teresa Costa [5] was dedicated to the formative aspects inherent to the use of the platform and databases provided by B-on Consortium (Knowledge Library Online). The reflection focused particularly on the return on the investment of providing such a comprehensive set of sources of online scientific information, and tried to find strategies to address this challenge. Training in the use of resources is a necessary strategy, highlighting the effect on the spread of use, particularly with regard to the training of trainers who can then replicate the training to users at institutions that make use of this platform. On the other hand, aspects such as adaptability and accessibility are highlighted as important vectors for the promotion of comprehensive training. In this sense, training in e-learning is a form displayed as a permanent and ubiquitous solution that supports the possibility of interactive learning by users. The author thus sought to sustain the argument that the effective use of the resources of B-on is enhanced by a larger, more diverse and more widespread training provision.

\subsection{Case 5 - Universidade de Lisboa, Faculdade de Medicina (Lisbon University, Faculty of Medicine)}

In the case of the Faculty of Medicine, Lisbon University, a comprehensive study of training was conducted in the context of the library [14]. This academic work, submitted by Susana Henriques for the degree of Master of Science in the field of Documentation and Information, proposed an educational project based on an institutional analysis. The issues that gave rise to her work were based on the idea of the integration of training in the academic curriculum and its implications. Henriques points as aspects to consider the statement of the strategic value of the library in higher education, and the recognition of qualifications and skills of librarians as promoters of educational success. She recommends that these professionals coordinate the training activities with faculty, building strong partnerships that aim to improve the learning processes of students and to empower the library user.

\subsection{Case 6 - Instituto Politécnico de Castelo Branco (Polytechnic Institute of Castelo Branco)}

The library of the Polytechnic Institute of Castelo Branco [15] conducted a study dedicated to understanding the informational student profile. The main objective of the study was to prepare the training aimed at this target audience, taking into account its features. One important finding is that the observed group believes they do not need training to use the library and refer to the internet as the most appreciated service. The self-perception of their skills will thus become a discouraging factor with regard to deciding to attend training offered by the library. The authors underline the poor utilization of available resources (space, tools, 
documents and information), mainly due to the lack of knowledge of their existence, of their functions and their capabilities. The study reveals that there is a lack of information which has to be tackled regarding library matters and the purposes of the catalog. That circumstance is translated into an inappropriate use of the library space, ignorance of the catalog as a potential tool for locating documents / information, ignorance of the rules about bibliographic referencing and, finally, the assertion that no training is required for using the library and its resources. The authors concluded that intervention by the libraries must necessarily stress their ability to motivate and stimulate their audience, using a basis of proximity and interrelationship from which to establish the necessary mediation actions between the information and the user.

\subsection{Case 7 - Universidade de Lisboa, Faculdade de Psicologia e Instituto de Educação (Lisbon University, Faculty of Psychology and Institute of Education)}

Finally, the last article [16] focuses on the reality of the library that serves two organizational units - Faculty of Psychology and the Institute of Education, Lisbon University. The article presents a theoretical background for the learning actions in information literacy as a tool of empowerment for the achievement of academic goals. Regarding the underlying theorization of university pedagogy, the article argues that it is by empowering students that a better training in information skills can be developed. These are the same skills that they could autonomously use throughout academic life.

\section{Discussion of Results}

The cross-analysis of the selected articles that represent the current reality and the state of the art of user training in university libraries in Portugal has revealed a few commonalities in the ideas of librarians. The first idea is that a better understanding of the target audience allows for better intervention and response to their needs. On the other hand, there is the idea that there is a weak profitability of informational resources available in university libraries. This finding has triggered suggestions and actions that are already under way in several libraries and that emerge as leitmotiv across the analyzed articles. This may be expressed in recommendations for the majority of university libraries:

- Insist on knowledge, on the part of students, of existing resources.

- Develop and affirm the intrinsic value of libraries for the personal and professional development of its users.

- Better communicate with target audiences.

- Actively disseminate training. 
- Understand the multiplying effect of training.

- Affirm librarians as promoters of educational success.

- Integrate the content of training in information literacy in the curriculum.

Information skills fall into one practical application frame and consist of locating, selecting, evaluating, using, synthesizing, and presenting information. These information skills are not expressed directly in any of the training programs suggested in the articles analyzed. On the contrary, librarians are observed to prefer presenting tools (such as databases, catalog, and software) that are explored and from which they demonstrate information skills in the form of exercises. This underlying trait of information literacy, omitting its direct expression, may have the disadvantage of lack of awareness of the research process, retrieval and presentation of information, if it is not clearly stated. On the other hand, it presents clear advantages when performing direct instruction, based on available information sources from libraries. These actions contribute to one of the four pillars of education promoted by UNESCO, namely learning to do. As successive searches are made on B-on, in catalogs, or in specific databases and reference managers are used, research becomes more proficient as does the recovery of relevant information and the detection and evaluation of relevant results for the topic of interest. It thus appears that the skills that seek to promote most training activities analyzed here are those relating to previous or preparatory processes in information management - the process of location, selection and evaluation of information - which is required to meet certain academic requirements.

It appears that teaching the use, synthesis and presentation of information of these skills is not relevant, although they are part of the cast of information skills advocated in international policy documents.

Indeed, in the simultaneous observation of the literature cited in the documents analyzed, although it is not conclusive, the most cited orientation document appears to be Information literacy competency standards for higher Education [17]. The international reception of information literacy theories is also made by citing studies, articles and several experiences in the scope. However, despite specific examples, it seems that Portuguese librarians do not address the training curricula in order to reflect all the components of information literacy.

Exceptions to this are the Nova University of Lisbon, through its Faculty of Science and Technology Library, and the University of Lisbon, with the library of the Faculty of Psychology and the Institute of Education. In their training activities, both libraries mention ideas related to structuring a scientific work, to registering information and to writing strategies. The widespread failure of this second batch of information skills on the part of librarians is a very interesting aspect that can be analyzed in light of the professional profile of the librarian.

The dimension of technicality (organization, classification and cataloguing of information) that underpinned the identity formation of libraries is the same one that has informed the profile of these professionals. Hence, the technical skills they have to share with the students are those regarding which they feel most 
comfortable. Areas associated with subjective aspects, such as writing skills and creativity in general, are relegated to the students themselves who, under the guidance of teachers, develop activities to put into action skills related to academic writing. In the training proposals presented here, these students should, so it appears, autonomously (though under the supervision of their Professor) find ways to summarize and present the information found, usually through a written work.

\section{Conclusions}

Investigations and studies on the role of librarians in higher education in Portugal are still incipient, particularly with regard to their skills, including teaching competences or pedagogical methods in user education. Information about training in information literacy is equally scarce, as found by the preceding analysis. In Portugal, so far there are no national initiatives for the study and promotion of IL across university libraries. We would like to suggest the creation of working groups in this regard, with common aims and activities, in order to strengthen IL in Portugal.

This study sought to contribute to the analysis of this reality. In a context where the demands of society encourage diversity and curricular flexibility in higher education, greater proficiency in research, understanding and use of information, and the purchase of tools for lifelong learning. This reflection is one step further towards future work in these areas.

\section{References}

1. Higgins J.P.T., Green S. (editors): Cochrane Handbook for Systematic Reviews of Interventions Version 5.1.0 [updated March 2011]. The Cochrane Collaboration, (2011). Available from www.cochrane-handbook.org.

2. Sanches, T.: O Contributo da Literacia de Informação para a Pedagogia Universitária: um Desafio para as Bibliotecas Académicas. Universidade de Lisboa, Lisboa (2013). Available from http://repositorio.ul.pt/handle/10451/10773

3. Amante, M.J.: Bibliotecas Universitárias: Semear Hoje para Colher Amanhã. In: 9 o Congresso Nacional de Bibliotecários, Arquivistas e Documentalistas: Informação para a Cidadania, o Desenvolvimento e a Inovação. BAD, Lisboa (2007) Available from http://hdl.handle.net/10071/346

4. Amante, M.J., Estremenõ Placer, A.I., Costa, A.F.: As Bibliotecas Universitárias na Sociedade do Conhecimento: o Imperativo da Colaboração. In: Borges, M.M., Sanz Casado, E.: A Ciência da Informação Criadora de Conhecimento. IUC, Coimbra (2009) Available from http://hdl.handle.net/10071/1561

5. Costa, M.T.: Formação B-on: Competências ao Nível da Utilização de Recursos e Serviços Electrónicos. In: Políticas de Informação na Sociedade em Rede: 10으 Congresso Nacional de Bibliotecários, Arquivistas e Documentalistas. BAD, Guimarães (2010) Available from http://comum.rcaap.pt/handle/123456789/495 
6. Segurado, T.: A Informação Estatística na Tomada de Decisão das Bibliotecas do Ensino Superior em Portugal. Universidade de Évora, Évora (2009). Available from http://hdl.handle.net/10071/2137

7. Segurado, T., Amante, M.J.: Avaliar para Melhorar: o Caso da Biblioteca do ISCTEIUL. In: 10 Congresso Nacional de Bibliotecários, Arquivistas e Documentalistas. BAD, Guimarães (2010) Available from http://hdl.handle.net/10071/1651

8. Lopes, C., Pinto, M.: IL-HUMASS - Instrumento de Avaliação de Competências em Literacia da Informação: um Estudo de Adaptação à População Portuguesa (Parte I). In: 10 을 Congresso Nacional de Bibliotecários, Arquivistas e Documentalistas. BAD, Guimarães (2010) Available from http://www.bad.pt/publicacoes/index.php/congressosbad/article/view/181/177

9. Rodrigues, E.: As Bibliotecas Universitárias e a Formação dos Estudantes de Engenharia no Domínio da Documentação/Informação. In: Multiculturalismo: comunicações: 5o Congresso Nacional de Bibliotecários, Arquivistas e Documentalistas. BAD, Lisboa (1994)

10. Pacheco, E. L. M.: A Literacia da Informação e o Contributo da Biblioteca Universitária. In: Informação para a Cidadania, o Desenvolvimento e a Inovação: 9.으 Congresso Nacional de Bibliotecários, Arquivistas e Documentalistas. BAD, Ponta Delgada (2007) Available from http://hdl.handle.net/10760/14483

11. Pacheco, E., Vargues, M., Sequeira, N.B.: A Literacia da Informação e o Ensino Superior: a Experiência na Biblioteca da Universidade do Algarve. In: Políticas de Informação na Sociedade em Rede: 10 Congresso Nacional de Bibliotecários, Arquivistas e Documentalistas. BAD, Guimarães (2010). Available from http://hdl.handle.net/10760/14482

12. Pacheco, E., Barradas, M.J.O., Sequeira, N.B.: Formação de Utilizadores na Biblioteca Universitária: um Estudo de Caso. In: Integração, Acesso e Valor Social: 11.으 Congresso Nacional de Bibliotecários, Arquivistas e Documentalistas. BAD, Lisboa (2012) Available from http://www.bad.pt/publicacoes/index.php/congressosbad/article/view/395

13. Roxo, A.I., Duarte, M.R.: Impacte do Serviço de Formação de Utilizadores da Biblioteca FCTUNL. In: Políticas de Informação na Sociedade em Rede: 10응 Congresso Nacional de Bibliotecários, Arquivistas e Documentalistas. BAD, Guimarães (2010) Available from http://hdl.handle.net/10362/4012

14. Henriques, S.: Literacia da Informação: Projecto para Formação de Utilizadores na Biblioteca CDI da Faculdade de Medicina da Universidade de Lisboa. Lisboa (2011) Available from http://hdl.handle.net/10451/6158

15. Rodrigues, M.E.P., Vaz, F., Menezes, M.H.: Contribuição para o Conhecimento do Perfil Informacional do Estudante do Ensino Superior. In: Integração, Acesso e Valor Social: 11. Congresso Nacional de Bibliotecários, Arquivistas e Documentalistas. BAD, Lisboa (2012) Available from http://www.bad.pt/publicacoes/index.php/congressosbad/article/view/302

16. Sanches, T.: Do Campo da Pesquisa ao Campus do Conhecimento: Instrumentalização da Literacia da Informação em Meio Académico. In: Integração, Acesso e Valor Social: 11. - Congresso Nacional de Bibliotecários, Arquivistas e Documentalistas. BAD, Lisboa (2012) Available from http://hdl.handle.net/10451/7116

17. ALA Information Literacy Competency Standards for Higher Education Association of College and Research Libraries. American Library Association, Chicago, IL (2000) http://www.ala.org/ala/mgrps/divs/acrl/standards/standards.pdf 
